\title{
THE MOST REALISTIC FACTORS STRENGTHEN THE EMPLOYEE'S PRODUCTIVITY
}

\section{The Qualitative Study of Labor Behavior in Area Indonesia.}

\author{
${ }^{1}$ Firmansyah, ${ }^{2}$ Adhy Firdaus. \\ ${ }^{1}$ Faculty members of STIE Ganesha, Jakarta, Indonesia. \\ ${ }^{2}$ Lecturer of Post Graduate Programs of STIE Ganesha, South Tangerang, Banten Province, Indonesia. \\ ${ }^{1}$ hafirman@stieganesha.ac.id 2 adhyfirdaus@stieganesha.ac.id \\ DOI: $10.31364 / S C I R J / v 8 . i 3.2020 . P 0320754$ \\ http://dx.doi.org/10.31364/SCIRJ/v8.i3.2020.P0320754
}

\begin{abstract}
The Labor's behavior and employee concern is always been an attractive issue for business owners. The interest in knowing what the employee expects from the company in return for their loyalty and high productivity is the best topic the company's stakeholders won't miss. Theoretically many scholars had their opinions concerning employee productivity. This research is focused on the real-life reasons for the employee to be more productive in the company. The research questions are what is the employee's expectations form the company? What makes the employee happy and enthusiastic to work? How is the working environment which the employees dream of?
\end{abstract}

The research used qualitative research methods with an in-depth interview data gathering and basic content analysis data processing.

The research found that management's appreciation, respect, and the employee's opportunity to express positive work creativity are the most realistic factor which strengthens the productivity of employees. Research findings contribute to the arguments for knowledge management.

Key words - Appreciation, creativity, employee productivity, respect, strengthens.

\section{INTRODUCTION}

The Labor's behavior and employee concern is always been an attractive issue for business owners. The interest in knowing what the employee expects from the company in return for their loyalty and high productivity is the best topic the company's stakeholders won't miss.

Theoretically many scholars had their opinions concerning employee productivity. The Role and Importance of Employee's Productivity in Industry 4.0 (Cresnar \& Nedelko, 2017) is one of the main concerns of today research. Employees' performance depends on various factors (Victoria, 2019).

This research is focused on the real-life reasons for the employee to be more productive in the company. The research questions are what is the employee's expectations form the company? What makes the employee happy and enthusiastic to work? How is the working environment which the employees dream of?

Wikipedia (2020) defines an employee is a term for workers and managers working for a company, organization or community. These people are the staff of the organization. In most modern economies the word "employee" means a person who works for a corporation. The relationship between employer and employee is different from that between the firm and a customer or client (Employee, 2020). From this definition, any person hired or employed by an employer to do a particular job or duty is an employee.

According to Learner Dictionary, enthusiastic is a feeling or showing strong excitement about something: filled with or marked by enthusiasm (Learner-Dictionary, 2020).

Productive and productivity is the condition or quality of producing something, when the productivity linked with the labor thus the labor productivity means measures the hourly output of a country's economy. Specifically, it charts the amount of real gross domestic product (GDP) produced by an hour of labor. Growth in labor productivity depends on three main factors: saving and investment in physical capital, new technology, and human capital (Investopedia, 2019). According to ILO, Labor productivity is an important economic indicator that is closely linked to economic growth, competitiveness, and living standards within an economy (ILO, 2020). 
An environment is a place where different things are such as a swampy or hot environment. It can be living (biotic) or non-living (abiotic) things. It includes physical, chemical and other natural forces. Living things live in their environment (Wikipedia, 2020).

The term work environment is used to describe the surrounding conditions in which an employee operates. The work environment can be composed of physical conditions, such as office temperature, or equipment, such as personal computers. It can also be related to factors such as work processes or procedures.

\section{RESEARCH METHOD}

All research aims to advance, refine, and expand the body of knowledge, establish facts and/or reach a new conclusion using systematic inquiries and discipline methods (Tie, Birks, \& Francis, 2019).

The task of all research is enlarging knowledge and understanding; this involves identifying and describing phenomena to improve understanding of those phenomena. Qualitative research is not experimental but descriptive and is carried out under conditions that resemble the everyday life of the people involved. (Cropley, 2019). The qualitative research is an approach for exploring and understanding the meaning individuals or groups ascribe to a social or human problems. The process of research involves emerging questions and procedures (Cresswell J. , 2014).

\section{Setting}

Qualitative research takes place in a natural setting (Creswell, 2003). Setting for this research is in the City of Tangerang Selatan or Tangsel on the Western side of Jakarta. Located approximately $30 \mathrm{KM}$ west Jakarta with a total area of $147,2 \mathrm{KM}^{2}$ and 1.593.812 people reside in this city. Tangsel City has plenty of companies such as Transportations, Communications, Trading; Accommodations service companies and Educational institutions such as Islamic State University - UIN- and The Ganesha Economics School of Higher Educations (STIE Ganesha). The companies and educational Institutions employ almost more than ten thousand people (TangSel-City, 2020). And since Tangsel is adjacent to the Capital City of Jakarta, lots of labor who works in Jakarta also reside in Tangsel as temporary residents. This setting is suitable for the research since it can provide the data needed for the research.

\section{Researcher}

Researchers are the lecturers and research staff of the postgraduate school of management and had lived in the city (setting area) for more than 4 years, and know the city and its people very well. The researchers do not have any relationship with the research subject and do not have a personal and institutional interest in the research subject either. This will eliminate the bias in research.

In Qualitative research, the researchers are the main instrument (Cresswell, Hanson, Cark Plano, \& Morales, 2007). This means that the researcher view of the topic and their credibility are important. The researcher views social phenomena holistically. (Creswell, 2003).

\section{Informants}

Informants were chosen from the Labor forces and the office manager in Tangsel. The researcher used a purposive sampling and snowball approach to find the right person to collect data.

First, the researchers found the gatekeeper who will guide to find suitable informants. From gatekeeper, the researchers found informant and then lead to the next informant, and next informants and finally to the last and got enough data that were sufficient for the research. In Qualitative research, the minimum number of Informants is not strictly defined (Firdaus A, 2019). Gatekeeper and informants were informed and explained briefly about the research and their position in the research and the safety of their identity. They were also informed about their freedom in this research, meaning that they can leave research any time they wanted. When they decided to terminate their participation in the research their identity is saved, it will not be released to other parties at any cost. The informants state their willingness to participate in research and gave the right to the researcher to use the interview and other materials for research in writing. They were given compensation for the time they spent during the research.

The researchers decided to have 1(One) gatekeeper and 3 (Three) informants for the research. The gatekeeper was a 55 years old gentleman from Western Sumatra who is married to a local lady. He is a holder of 'Sarjana Ekonomi' degree from College in Jakarta. He used to work as a supervisor at a transportation company, but right now he owns a culinary business at the traditional market in Tangsel City. The second participant, the first Informant was a 40 years old married gentleman who works for a trading company in Tangsel, his occupation is Customer relation officer, his line of duty is to ensure that merchandise ordered by customers delivered and received in good conditions and on time. In other words, ensuring customer satisfaction. The third participant, the second informant was a 35 years lady who married a handsome understanding husband. She works as a secretary at the administration office of the reputable undergraduate Economics college in Tangsel. Herline of duty is to administer student records and academic achievements. The fourth participant, the third informants was a 25 years old young man who just graduated from university and working as a sales supervisor at the department store. 
Table. 1 describes the demographic data of Informants.

TABLE.1 Demographic Data of Informants.

\begin{tabular}{|l|l|l|l|l|l|l|l|}
\hline No. & INFORMANTS & GENDER & AGE - yr & MARRIED & EDUCATION & OCCUPATION & REMARKS \\
\hline 1 & Gatekeeper/Gk & M & 55 & Married & $\begin{array}{l}\text { S-1 /Bachelor } \\
\text { degree }\end{array}$ & $\begin{array}{l}\text { Small } \\
\text { restaurant } \\
\text { owner }\end{array}$ & \\
\hline 2 & Inf-1 & M & 40 & Marriedd & $\begin{array}{l}\text { S-2/ Master } \\
\text { degrre }\end{array}$ & $\begin{array}{l}\text { Customer } \\
\text { satisfaction } \\
\text { officer }\end{array}$ & \\
\hline 3 & Inf-2 & F & 35 & Marrried & $\begin{array}{l}\text { S-2 / Master } \\
\text { degree }\end{array}$ & Secretary & \\
\hline 4 & Inf-3 & M & 25 & No-Mard & $\begin{array}{l}\text { S-1 / Bachelor } \\
\text { degree }\end{array}$ & $\begin{array}{l}\text { Sales } \\
\text { supervisor }\end{array}$ & \\
\hline
\end{tabular}

\section{Data Collection}

In the qualitative research, data typically collected in the participant's setting (Cresswell J. , 2014). Data was collected from the informants by conducting a one to one and in-depth interview in the place which is comfortable with the informants' choice. This is to make informants feel free and happy to tell their feelings, perceptions, and experiences.

The interviews were recorded with a SONY digital recording device. The interview notes were used to note the body language and gestures of the interviewees at the time of the interview.

Researchers made one more time observation of the setting and make notes of the events and the situations in the settings.

The recorded interviews then transcribed immediately after the interviews finished. This transcription was done by the other party to maintain the truth value of truthfulness.

Peer debriefing was performed with colleagues to keep the research on the right track and research reliability is maintained.

For the sake of accuracy, a member checking was conducted.

\section{Data Analysis}

In qualitative research, data analysis inductively building from particulars to general themes and the researcher making interpretations of the meaning of the data (Cresswell J. , 2014).

The qualitative research is fundamentally interpretive, this means that the researcher interprets the data (Creswell, 2003).

Interview transcriptions were read carefully several times. The interview recordings listened thoroughly while reading its transcription. Then the significance sentences were remarked. The discovering significant sentences then grouped into themes. The main theme then drawn from themes. The main theme was concluded to be findings. Tabel.2 gives a slight illustration of how the significant sentences drawn to themes and finally become findings.

Tabel.2 Significant sentences, Themes, Main Theme.

\begin{tabular}{|c|c|c|c|}
\hline No. & SIGNIFICANT SENTENCES & THEMES & MAIN THEMES \\
\hline 1 & $\begin{array}{l}\text { Gatekeeper/Gk:" it feels good when your } \\
\text { job is appreciated, and the appreciation } \\
\text { from your boss makes you want to do the } \\
\text { job better and faster." } \\
\text { Inf-1: "I feel like flying when the boss } \\
\text { said 'you are the boss around here', with } \\
\text { his thumb up sign. And I will do my best } \\
\text { to prevent consumers from complaining" } \\
\text { Inf-2: " like I could work all day when } \\
\text { my chief appreciated my job". "Tired } \\
\text { and exhausted instantly disappear and it } \\
\text { feels like I can work again and again". } \\
\text { Inf-3: my work spirit increased with the } \\
\text { award given by management" }\end{array}$ & $\begin{array}{l}\text { the appreciation from your } \\
\text { boss makes you want to do } \\
\text { the job better and faster. } \\
\text { with his thumb up sign. And } \\
\text { I will do my best to prevent } \\
\text { consumers from } \\
\text { complaining. } \\
\text { like I could work all day } \\
\text { when my supervisor } \\
\text { appreciated my job } \\
\text { my work spirit increased } \\
\text { with the award given }\end{array}$ & $\begin{array}{l}\text { Management } \\
\text { Appreciation }\end{array}$ \\
\hline 2 & Gatekeeper/Gk: "your employee is also a & $\begin{array}{l}\text { employee is also a human, } \\
\text { they too need to be }\end{array}$ & Management respect to \\
\hline
\end{tabular}




\begin{tabular}{|c|c|c|c|}
\hline & $\begin{array}{l}\text { human, they too need to be respected" } \\
\text { Inf-1: "as an employee we have rights, } \\
\text { the management should know that and } \\
\text { should respect our rights, when they do } \\
\text { so there is no reason for us not to do the } \\
\text { job better." } \\
\text { Inf-2: "respect and appreciation } \\
\text { encourage us to work more effectively } \\
\text { and more efficiently." } \\
\text { Inf-3: "I work more passionate when the } \\
\text { management respects me as a person." }\end{array}$ & $\begin{array}{l}\text { respected. } \\
\text { the management should } \\
\text { know that and should respect } \\
\text { our rights, } \\
\text { respect and appreciation } \\
\text { encourage us to work more } \\
\text { effectively and more } \\
\text { efficiently. } \\
\text { I work more passionate } \\
\text { when the management } \\
\text { respects me }\end{array}$ & the employee \\
\hline 3 & $\begin{array}{l}\text { Gatekeeper/Gk: "usually I ask my team } \\
\text { opinion about how they want to do the } \\
\text { task for a better outcome." } \\
\text { Inf-1: "they always have ideas to do a } \\
\text { work better, it's just I don't have the } \\
\text { authorities to give permissions." } \\
\text { Inf-1: "if only they allow us to use our } \\
\text { ideas to complete the job better and } \\
\text { faster, I mean efficient and effective." "It } \\
\text { would give the company a great } \\
\text { advantage and profit." } \\
\text { Inf-2: "I know how to finish the work } \\
\text { better and faster, but I have no right to } \\
\text { decide, so I do it the same usual way. } \\
\text { Boring." "and when we bored, we rather } \\
\text { doing something else or play with our } \\
\text { smartphone." }\end{array}$ & $\begin{array}{l}\text { usually, I ask my team } \\
\text { opinion about how they want } \\
\text { to do the task for a better } \\
\text { outcome. } \\
\text { they always have ideas to do } \\
\text { a work better } \\
\text { if only they allow us to use } \\
\text { our ideas to complete the job } \\
\text { better and faster, } \\
\text { when we bored, we rather } \\
\text { doing something else or play } \\
\text { with our smartphone. } \\
\text { if we could have the freedom } \\
\text { oure creativity } \\
\text { finishing the job faster }\end{array}$ & $\begin{array}{l}\text { Freedom to be creative in } \\
\text { completing the tasks } \\
\text { correctly, effectively, and } \\
\text { efficiently }\end{array}$ \\
\hline
\end{tabular}

\section{FINDINGS}

The research found that

1. the management appreciation,

2. Management respect to the employee, and

3. Freedom to be creative in completing the tasks correctly, effectively, and efficiently

Are the most important and realistic factors that raise the employee's productivity.

\section{DISCUSSION}

According to Jackson, K. (2019) Productivity in the workplace can be increased by improving workplace conditions and ensure employees are happy (Jackson, 2019), but how to make employees happy is not stated. From the research, the researcher found 
that one of the real factor that strengthens the employee productivity is the management's appreciation of the job well done by the employee. This fact has emerged in the following significant sentences of interviews.

Gatekeeper/Gk: "your employee is also a human, they too need to be respected"

Inf-1: "as an employee we have rights, the management should know that and should respect our rights, when they do so there is no reason for us not to do the job better."

Inf-2: "respect and appreciation encourage us to work more effectively and more efficiently."

Inf-3: "I work more passionate when the management respects me as a person."

Gartenstein (2017) argues that a productive workplace improves the relationship with customers by enabling the company to complete projects on time and even earlier. Because happier employees are friendlier to customers. This in line with the research findings that to make the employee happy management could give them some appreciation, respect and allowing them to be creative in completing the tasks correctly, effectively, and efficiently. This will make them feel comfortable with the workload and workplace which in turn raises the employee productivity. The following statements indicate those facts.

Gatekeeper/Gk: "usually I ask my team opinion about how they want to do the task for a better outcome."

Inf-1: "they always have ideas to do a work better, it's just I don't have the authorities to give permissions."

Inf-1: "if only they allow us to use our ideas to complete the job better and faster, I mean efficient and effective." "It would give the company a great advantage and profit."

Inf-2: "I know how to finish the work better and faster, but I have no right to decide, so I do it the same usual way. Boring." "and when we bored, we rather doing something else or play with our smartphone."

Inf-3: "only if we could have the freedom to use our creativity finishing the job faster."

People are sources of the creative added value, therefore are an integral part of any organization's future success (Cresnar \& Nedelko, 2017).

\section{CONCLUSIONS}

The researchers concluded that for the organization to improve employees productivity has to change its management's attitudes that are to give more appreciation of the employees work outcome, and more respect to the employee's opinion of the work environment, and give freedom for the employee to be creative in completing the tasks correctly, effectively, and efficiently for a job well done.

The appreciation, respect, and freedom to be creative in completing the tasks correctly, effectively, and efficiently are the real factors that strengthen employee's productivity.

The research findings contribute to the arguments for knowledge management.

\section{FUTURE RESEARCH}

The research was carefully conducted, but further research is suggested to acquire more evidence to understand the relationship between employer and employee. Future research should be conducted in larger settings and more informants from any discipline.

\section{ACKNOWLEDGMENT}

The researcher would like to appreciate and give thanks to the informants for their willingness to participate in the research. The researcher also want to thang to those who have made this research was easy and fulfilled with no problems. May Allah bless us all. Alhamdulillahi Robbil Alamein.

\section{Bibliography}

Employee. (2020, 03 26). Retrieved from Wikipedia.org: https://simple.wikipedia.org/wiki/Employee

Cresnar, R., \& Nedelko, Z. (2017). Mechanism for Ensuring Competitiveness in the International Labor Market and Personel Management. In R. Cresnar, The Role and Importance of Employee's Productivity in Industry 4.0 (pp. 120-133). Riga, Latvia: ISMA University. Retrieved 03 27, 2020, from https://www.researchgate.net/publication/3204710377

Cresswell, J. (2014). Research design: Qualitative, Quantitative, and Mixed Methods Approaches (4th ed.). Thousand Oaks, California, USA: SAGE Publications, Inc.

Cresswell, J. W., Hanson, W. E., Cark Plano, V. L., \& Morales, A. (2007). Qualitative Research Design. The Counselling Psychologist, 35(2), 236-264. doi:10.1177/0011000006287390 
Creswell, J. W. (2003). Research Design: Qualitative, Quantitative, and Mixed Methods Approaches (Secon Editions ed.). (C. D. Laughton, Ed.) Thousand Oaks: SAGE Publications.

Cropley, A. (2019). Introduction to Qualitative Research Methods (2nd ed.). Riga, Latvia: Zinatne. doi:10.13140/RG.2.1.3095.6888

Firdaus A. (2019, Nov). Student Fearlessly Attacking Teacher and Others: A Qualitative Study of Ethics. Open Journal of Social Science, 7, 113-125.

Gartenstein, D. (2017, September 26). Why Is Productivity Important in the Workplace. Retrieved from bizpluent.com: https://www.bizfluent

ILO. (2020, 03 26). Labor Productivity - ILO. Retrieved from ilo.org: https://www.ilo.org

Investopedia. (2019, July 25). Labor Productivity Definition. Retrieved 03 26, 2020, from investopedia.com: https://www.investopedia.com>economi

Jackson, K. (2019). 8 Ways to Increase Productivity in the Workplace. Retrieved from businesstown.com: https://www.businesstown.com

Learner-Dictionary. (2020, 03 26). Enthusiastic. Retrieved from LearnerDictionary.com: http://www.learnersdictionary.com/definition/enthusiastic

TangSel-City. (2020, 03 25). Pemerintah Kota Tangerang Selatan. Retrieved $03 \quad 26, \quad 2020, \quad$ from https:www.tangerangselatankota.go.id

Tie, Y. C., Birks, M., \& Francis, K. (2019). Grounded Theory Research: A design framework for a novice researcher. SAGE Open Medicine, 7, 1-8. doi:10.1177.20503121.18822927

Victoria, K. S. (2019, April 14). Employee Productivity and Organization Performance: A Theoretical Perspective. MPRA Paper, 1. Retrieved 03 27, 2020, from https://mpra.ub.uni-muenchen.de/93294/

Wikipedia. (2020, February 15). Natural Environment - Wikipedia. Retrieved from wikipedia.org: htpps://en.m.wikipedia.org 